\title{
Climate change and growing megacities: hazards and vulnerability
}

Julian C. R. Hunt MA, PhD, FIMA, FRS

Emeritus Professor, Department of Earth Sciences, University College London, London, UK; Trinity College, Cambridge, UK

Yasemin D. Aktas BSC, MSC, PhD

Senior Research Associate, Epicentre Research Group, Department of Civil, Environmental and Geomatic Engineering, University College London, London, UK

\section{Alex Mahalov MSc, PhD}

Dean's Distinguished Professor, School of Mathematical and Statistical Sciences, Global Institute of Sustainability, Arizona State University, Tempe, AZ, USA
Mohamed Moustaoui DEA, PhD

Associate Professor, School of Mathematical and Statistical Sciences, Global Institute of Sustainability, Arizona State University, Tempe, AZ, USA

Francisco Salamanca BSC, MSc, PhD

Assistant Research Professor, School of Mathematical and Statistical Sciences, Global Institute of Sustainability, Arizona State University, Tempe, AZ, USA

Matei Georgescu BSc, MSc, PhD

Associate Professor, School of Geographical Sciences and Urban Planning, Arizona State University, Tempe, AZ, USA (corresponding author: matei.georgescu@asu.edu)

This paper is a review of geophysical and climatic trends associated with extreme weather events and natural hazards, their implications for urban areas and the effects of continued environmental modification due to urban expansion. It discusses how urban design, technological development and societal behaviour can either ameliorate or worsen climate-induced hazards in urban areas. Pressures - ranging from excessive rainfall causing urban flooding to urban temperature extremes driving air pollution - require more attention to understand, model and predict changes in hazards in urban areas. It concludes that involving different techniques for data analysis and system modelling is more appropriate for practical decision-making than a purely reductionist approach. Successfully determining the future environment of megacities will, however, require joint action with societally informed decision makers, grounded in sound scientific achievements.

\section{Introduction and overview}

From the earliest times, socio-economic factors and the ease of withstanding natural hazards in larger groups have led people to conglomerate. Throughout the world, from the smallest communities to the largest cities, these gatherings have formed selfreplicating patterns of organisation (Batty, 2008; Hunt, 2005). However, as the Second UN Habitat Conference in 1996 recognised (UN, 1996), cities, 'especially in developing countries', can also be responsible for the degradation of regional environments with harmful impacts for people and ecosystems, including deterioration of health and safety, increased air pollution, inadequate sewage and water management distribution systems and modification of patterns and intensities of storms and floods (Grimm et al., 2008; Hondula et al., 2014; Hunt, 2009a). Risks from disease and pandemics coupled with increased exposure owing to population increase and climate change also have implications for future vulnerability of urban areas (Hunt et al., 2016).

While cities serve as important agents that provide economic (e.g. employment), social (e.g. education) and a host of biophysical benefits (e.g. access to clean water and sanitation), their increasing size also places undue strain on infrastructure, increases energy demand and has led to ecological degradation (Grimm et al., 2008). As this paper further explains, the increasing size and population of cities generally lead to worsening of environmental hazards. In addition, these factors extend the distances around cities where hazards can be exacerbated. This is why cities are also becoming more vulnerable to hazards produced by other megacities located upwind and by upwind environmental dangers, such as smoke from burning and pollutants from shipping (e.g. Cheng and Chan, 2012;
Lin et al., 2014; Li et al., 2015; Zhang et al., 2011). As cities and clusters of cities, or conurbations, expand, their energy use (Madlener and Sunak, 2011) and pollution emissions increase (Akimoto, 2003). Cities can also alter the adjoining rural environment and the rivers and coasts that are so crucial to the livelihoods of small communities and natural ecosystems (Aguilar, 2008; Ehrenfeld, 2000; Georgescu et al., 2009; Lee et al., 2006; Li et al., 2016a; Salvati et al., 2012; Shao et al., 2006; Yang et al., 2016a). In particular, although recent estimates indicate cities take up less than $1 \%$ of the Earth's landmass (Schneider et al., 2010), they are responsible for a disproportionate amount of long-lived greenhouse gas (GHG) emissions (Satterthwaite, 2008; UN, 2007).

This paper is first a review of current and projected extreme weather event trends and associated natural hazards, as well as of most recent studies in the field. Second, the authors consider the effects of these occurrences on urban hazards and their impact on urban environmental vulnerability and sustainability. The conclusions highlight how studies of hazards and vulnerability provide the basis for estimating impacts and policy development.

\section{Trends in climate-related hazards}

Trends in climate-related hazards will be discussed in two subsections focusing mainly on their relation to regional climate extremes and urban growth (Figure 1).

\subsection{Extremes in regional climate and environment}

New observations and earth system models are showing how the climate has varied in the past in different characteristic ways (IPCC, 2014). Weather patterns are determined not only by 


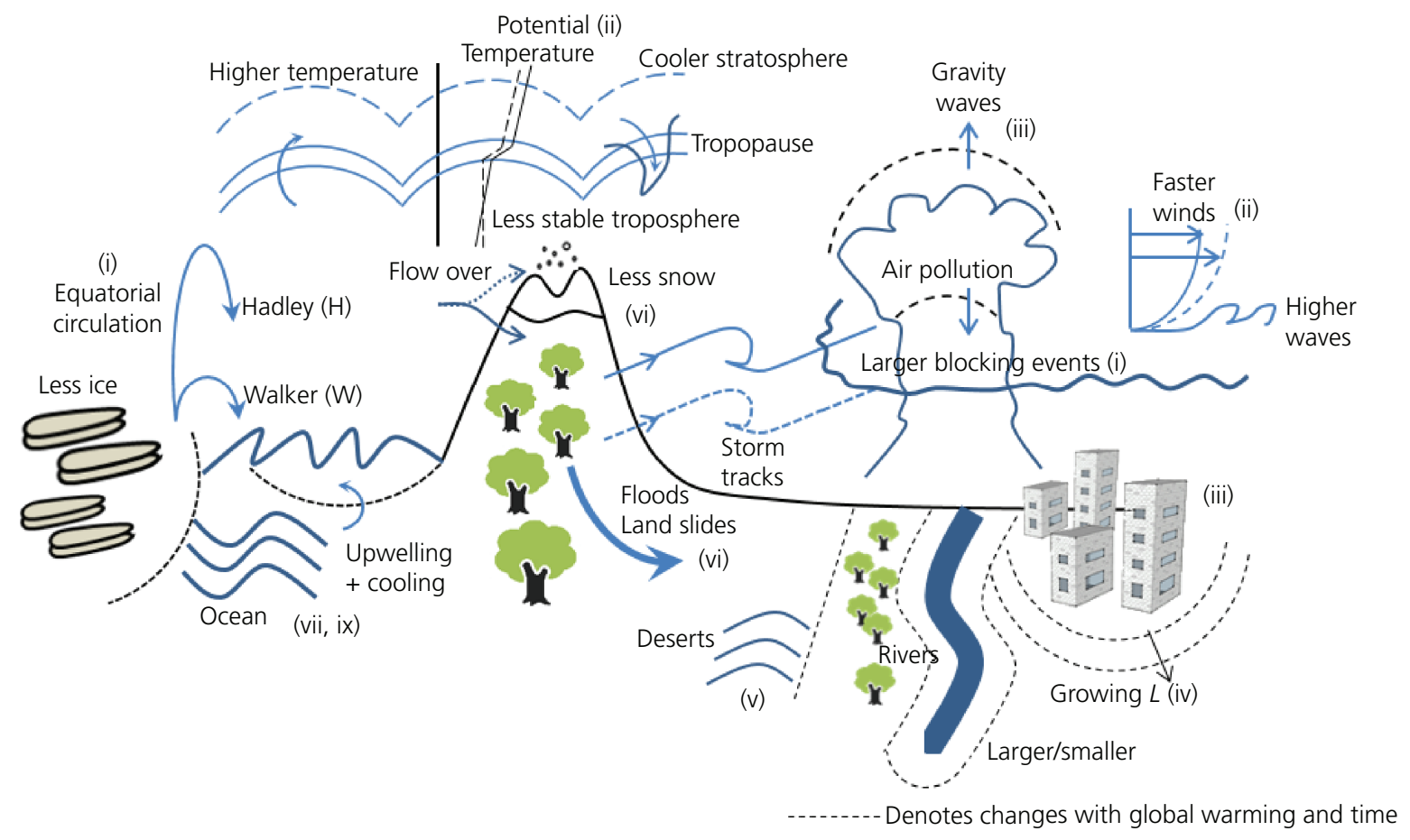

Figure 1. Main natural effects and hazards influenced by climate change. Atmosphere - large fluctuations in ocean basin scale circulations (i); vertical wind, temperature profiles (ii); intense air pollution (iii). Land - growth in urban areas (iv); desertification (v); reduced snow and land ice, with more floods on mountainous terrain, causing landslides and flooding (vi). Ocean and water - changes in coupled ocean-atmosphere circulations in tropics and polar regions (vii); rivers systematically growing or shrinking (viii); variable sea level rise (ix). L, size of urban area

climate, but also by orographic factors and other elements of the earth climate system with their own intrinsic variability (Schellnhuber et al., 2004). Over millennia, familiar atmospheric circulations such as temperate westerly winds and subtropical trade winds have persisted, even through ice ages (Houghton, 2015). However, although hemispheric oceanic circulations such as the Gulf Stream have endured, there have been large fluctuations, affecting ocean temperatures in subarctic regions (Broecker, 2010). Observational evidence reveals local climatic effects associated with natural variations in atmospheric winds and ocean currents over annual and decadal periods - for example, the El Niño-Southern Oscillation - and movements and variability of zones of forestation and desertification, such as the once-in-a-century southward movement of the Sahel in the 1970s.

Palaeoclimate models, and biochemical measurements, now show that humans have also played a role in influencing the regional variability of climate, originally through agricultural and forestry management and, more recently, through the development of built environments and GHG emissions (Hunt, 2005; Lentz et al., 2014). For example, the magnitude of the current melting of the Arctic summer ice and glaciers across the world is larger than what has occurred naturally since the last ice ages about 10000 years ago. The conclusion of IPCC (2014) is that this trend is likely to be the result of human effects, although high levels of internal variability can mask or interrupt the visibility of anthropogenically induced changes (Swart et al., 2015). A schematic diagram illustrating the diversity of natural effects and hazards influenced by climate change is shown in Figure 1.

IPCC (2014) concludes with high confidence that globally averaged near-surface temperatures will remain essentially constant for centuries even if anthropogenic emissions were to stop completely, unless there is a considerable net removal of carbon dioxide from the atmosphere. Furthermore, the continued decline of biological species associated with a changing climate is likely to endure unless the current trend in climate change begins to reverse. Recent measurements suggest that ice sheet temperatures may have already risen to the point where polar and mountain ice sheets and glaciers are beginning to fracture and slide into the ocean at a sufficient volume rate that they may continue to do so, even if the global average temperature of the forthcoming 200-300 years returns to what it was in 1850. This would cause significant sea level rise of several metres over the next millennium, resulting in catastrophic flooding and associated impacts on global society (IPCC, 2014). The current scientific majority view is that unless the future level of human influence on climate were to decline sometime during this century through global action (therefore halting the current rise of carbon dioxide emissions by or prior to mid-century; see the study by Stern (2006)), the aspects of the climate system (e.g. biosphere) will begin to change irreversibly (Lenton et al., 2008). This is the 
assumption of much current policy-making and is the subject of this review. However, this notion is not shared by the entire scientific community (Lawson, 2008). For example, while Solomon et al. (2009) argue that ice cap loss, hence sea level rise, is irreversible due to the longevity of atmospheric carbon dioxide emissions and already-risen ocean temperatures, Notz (2009) defends that there is no 'tipping point' for the loss of Arctic summer sea ice; therefore, sea ice is more likely to recover if climate warming is stopped by reversing carbon dioxide emissions to pre-industrialisation levels (if not prior to), as supported also by Tietsche et al. (2011). Conversely, the irreversibility of the ice sheet loss covering Greenland and the West Antarctic cannot be ruled out (Notz, 2009).

Recent analysis of climate prediction models and observational analysis indicate that while short-term trends (i.e. decadal scale or less) may not necessarily reveal long-term trends, the effects of increasing carbon dioxide emissions have played an important role in global warming, generally exceeding $0 \cdot 1^{\circ} \mathrm{C} /$ decade, since the middle of the previous century (Tollefson, 2016). Of key relevance for urban areas are the effects on the variability of climate, including their impacts on the global environment and society. Atypical events include 'extreme' events, defined broadly as events that differ from average weather and climate and/or that may persist over longer periods. Other atypical events are the significant changes in trends, including those owing to the occurrence of extreme events (Hov et al., 2013; IPCC, 2012). There are significant similarities between the main features of climate variability and other complex systems. An important characteristic is that, as fluctuations increase in frequency and magnitude, the non-linear interactions between the various components of the processes under investigation become more significant. In addition, physically based reductionist models become more reliable than purely statistical extrapolations based on past events (Hunt et al., 1996, 2012).

An example of short-term, high-magnitude events is strong convective updrafts and downdrafts, resulting from higher surface temperature, deeper troposphere and cooler stratosphere, which lead to higher rainfall intensity (now reaching $200 \mathrm{~mm} / \mathrm{h}$, double its value 10 years ago in South-east Asia; see the studies by the Hong Kong Observatory (2016), Wong et al. (2011) and Lee et al. (2010)). Consequently, increased frequency of lightning has been observed (Hunt et al., 2010; ten Hoeve et al., 2012) with a wider global distribution extending to the Arctic regions, as demonstrated by regular monitoring from satellites and globally from ground networks. This trend is leading to enhanced fire risk, forest degradation and destruction, more rapid run-off and consequential drought in some mountainous areas. These trends in convective storm events are associated with alteration in the changing nature of tornadoes with increased maximum wind speeds and greater widening of the affected regions (Elsner et al., 2015; Hunt and Hangan, 2013), particularly in south-eastern USA. However, observational analysis for other portions of the USA indicates a decreasing or near-zero trend in tornado temporal variability since
1950 (Guo et al., 2016), highlighting the importance of regionally based impact and vulnerability analysis.

Equally important types of extremes include periods of very warm or cold weather, rainy or snowy or very windy, which occur more frequently and persist over considerably longer periods than observed historically (Heim, 2015; IPCC, 2014; Matthews et al., 2016; WMO, 2013). Model simulations combined with physical arguments and exploratory analysis of recent global weather anomalies have concluded that such 'blocking' events will occur more often and last longer (Cassou and Guilyardi, 2007; Li et al., 2012). Sometimes, these events occur in a region simultaneously as climatic anomalies in other regions (Cheung et al., 2012). A recent notable illustration was the extreme 2010 flooding in Pakistan, which was associated with blocking in western Russia and persistent high temperatures in Moscow. Importantly, not all global computer models have come to this conclusion (Pelly and Hoskins, 2003).

Global climate modelling has progressively become more useful (i.e. since the 1970s) as spatial resolution has improved, leading to better representation of the key regional variations of planetary climate. The incorporation of urban canopy models within earth system models enables improved understanding of the interacting components of the earth system jointly with human activities (e.g. Li et al., 2016b, 2016c). Deficiencies in the representation of the marked trends and fluctuations in regional climate remain, such as mountainous regions (with reduced snowmelt and extremes in flooding) and polar regions associated with ocean-atmosphere-cryosphere interactions, and in modelling the lower tropical atmosphere, including the particular effects of urban areas at high spatial resolution (Shaffer et al., 2016).

\subsection{Climate change and urban growth leading to increased hazards and vulnerability}

Although the great cities of the world were largely founded for furthering trade, they were also designed, in part, to protect their citizens from natural and artificial hazards, including those associated with extreme weather conditions (Hunt 2009b, 2013). However, urban hazards may become greater, as human activities change and the overall size of the city (denoted by diameter $L$ in Figure 2) grows. In Asia and Africa, an additional 16\% increase in the total urban population is expected for both continents by 2050 (UN, 2014) (for more information on increase in urban population see World Bank (2017)). This is a significantly faster rate than that at which global climatic parameters are changing, such as the annual average temperature increase relative to preindustrial values (doubling over about 70 years) (for Chinese megacities, see the study by Chan and Yao (2008)). These changes are likely to lead to increased energy use and emissions of pollution. In addition, recent research has shown that projected impacts on near-surface temperature within urban areas are of the same order of magnitude as the effects due to large-scale climate change (Georgescu et al., 2013, 2014), underscoring the significance of cities as instruments of adaptation and mitigation. 


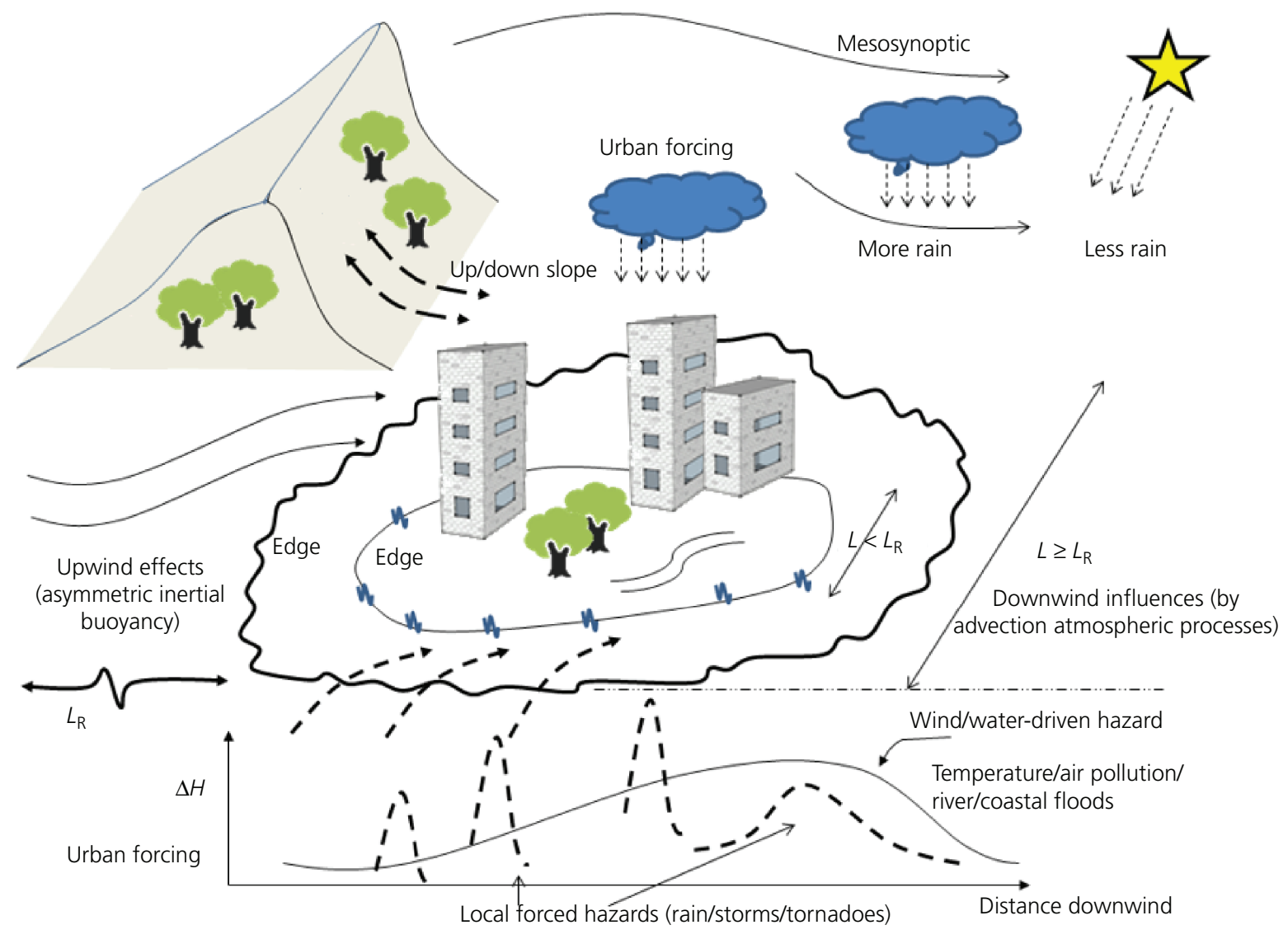

Figure 2. Increased hazards $(\Delta H)$ in urban areas in relation to urban forcing. When the size of the urban area $(L)$ becomes equal to or greater than $L_{R}$ (i.e. Rossby radius), the overall climatic hazards become typically more asymmetrical with a significant skew in the downwind direction. In this diagram, air motion is from left to right, and, as shown in the graph at the bottom, air pollution, mean temperatures and cumulative wind-driven hazard(s) increase with the distance downwind

Even with no change in the form of or the type of activities within a city, as the built-up area (i.e. size) and energy use increase, differences in temperature and humidity between the urban and rural areas grow significantly. Atmospheric flows are changed as a result of increased convection and turbulence. In desert areas (such as central China), strong inversion layers and dust lead to trapping of air pollution. In addition, the larger the city, the larger the total emissions of air pollutants and the higher the concentration (approximately in proportion to $L$; Figure 2). As their size increases above the characteristic 'mesoscale' distance that is, Rossby radius, $L_{\mathrm{R}}$ (Hunt et al., 2004) - the influence of the earth's rotation becomes significant at mid-latitudes. The physico-chemical properties of the air and water, and many aspects of the biosphere, depend on the relative sizes of green and built-up areas (Figure 2). Changes in these properties also depend on the buildings and planning of cities, their infrastructure and people's social behaviour patterns and government structures (e.g. Eakin et al., 2017), which vary between regions and countries and among large and small cities or even rural areas. In addition, most people spend about $80 \%$ of their time indoors, where environmental factors (e.g. temperature, air circulation and quality and humidity) are generally designed for much of the time to be markedly different from those outside (Rupp et al., 2015; Sailor, 2014). Indoor environmental control affects energy use and the actual levels of temperature and air quality experienced by occupants (Hunt and Li, 2014), but have consequential implications for outdoor environments (e.g. Salamanca et al., 2014; Taleghani et al., 2013).

In 'low-rise' megacities, the average heights of buildings are approximately constant (e.g. in Europe, Africa and some US cities such as Phoenix, Arizona), although most now have one or more central business districts, which have incorporated buildings of greater vertical dimension. However, in 'high-rise' megacities in Asia and South America, the average level of buildings has continued to rise relative to the narrow spaces between buildings. In both types of megacities, as $L$ extends over $30-100 \mathrm{~km}$, it becomes comparable with the size of the $L_{\mathrm{R}}$ mesoscale weather patterns (Hunt et al., 2004). Over this distance, winds tend to change direction as air passes over the city and continues to affect the atmospheric boundary layer and patterns of precipitation downwind (Cheng and Chan, 2012; Li et al., 2013a). 
In low-rise cities whose forms, with few exceptions, are not changing significantly, the populations are increasing, approximately in proportion to the area - that is, $L^{2}$ (Hunt et al., 2011). But in high-rise cities with rising population densities, the total population is rising at a faster relative rate. Consequently, stationary energy sources such as those used in heating/cooling/ servicing buildings and for supplying industries and water (of particular relevance in California; see the study by Andrew (2009)) are increasing slightly more rapidly than $L^{2}$. However, the additional energy used for transportation (except in cities with high usage of public transportation that are also more likely to integrate technological advancements - such as those mentioned by Carrington (2016)) is increasing significantly more rapidly as cities grow. Because the lengths of journeys in urban areas increase with $L$, and the population and incomes are increasing as $L^{2}$, the heat released per unit area by transportation is increasing in proportion to $L$ (Hunt et al., 2011). The energy for buildings, industry and road transport is generally supplied from outside built-up areas. New low-carbon-dioxide energy sources will therefore be necessary to avoid the contribution of urban areas to global emissions of harmful pollution (Kammen and Sunter, 2016).

The thermal environment affected by the city is determined by the heat capacity of buildings, differing properties of urban land surfaces (e.g. absorption or reflection of solar radiation), local heat emission from energy systems (e.g. air conditioning (AC)), heat from transportation (Sailor, 2011) and other anthropogenic sources such as reradiation from buildings and traffic. Equally important is the reduced ventilation caused by wind resistance of buildings and, in some cities, the reduction of solar radiation produced by dust and particles of air pollution. These factors, which can be modified by planning, building design and operation of urban systems, alter the surface and temperatures inside and outside buildings (Georgescu et al., 2015). During summer periods, temperatures are raised inside the urban area for longer periods compared with rural areas, whose temperatures decrease at a faster rate after sunset. The average temperatures over $24 \mathrm{~h}$ in urban areas can exceed rural temperatures by $5^{\circ} \mathrm{C}$ or more, with serious implications on energy use and health, although this value has considerable geographical and seasonal dependencies. Importantly, the urban heat island (UHI) phenomenon in highdensity cities such as Hong Kong is rather due to anthropogenic impacts, whereas in low-rise, less compact cities, the temperature increase is additionally governed by the re-emission of energy absorbed by the built environment (Yang et al., 2016b). While the UHI can reduce the need for heating in cold seasons, its effect will considerably increase energy use for cooling purposes during the summer (see US Department of Energy, 2013). Compounding the aforementioned changes in the physical environment are implications of, for example, extreme heat events (EHEs) in cities, with broad health consequences (Hajat et al., 2007, 2014; Hoshiko et al., 2010; Huynen et al., 2001; O'Neill and Ebi, 2009). But if streets are covered with trees, or roofs with vegetation, the shade and evapotranspiration lower daytime peak urban temperatures (Georgescu, 2015; Li and Norford, 2016;
Maggiotto et al., 2014; Middel et al., 2015; Tan et al., 2016; Yang et al., 2016c). In large south-eastern Asian cities (e.g. Li et al., 2013b), the UHI typically exceeds $2^{\circ} \mathrm{C}$ at night. By contrast, in large cities in continental climates (with populations greater than five million people) during high-pollution episodes in winter, the urban temperatures can be lower compared to rural areas throughout the diurnal cycle.

The effect of heat release in the city also affects the variation of temperature as the air moves across the city, with maximum values where high-rise buildings are concentrated in the centre of the city and towards the downwind side. The larger the city, the greater this effect is. Over the neighbourhood scale of $1-3 \mathrm{~km}$, temperatures are raised or lowered by parks, rivers, buildings and the presence of other urban forms (Connors et al., 2013; DecletBarreto et al., 2013). A distribution of smaller parks lowers the average temperature more than a few large parks (Bohnenstengel et al., 2011) and reduces the impacts of heatwaves as shown in mortality statistics for New York City (J. Huang, personal communication, Hong Kong University, Hong Kong, 2013). Such considerations bring to light the significance of urban design and form (Connors et al., 2013; Zhou et al., 2011), which necessitate discussion within a broader urban sustainability framework than has been acknowledged to date (Georgescu et al., 2015).

\subsubsection{Example 1: energy use in a desert urban area}

An example of the complexity by which urban areas can modify environmental hazards is associated with the heat emitted by AC systems. Physics-based modelling simulations accounting for the variation in people's behaviour have been confirmed by variations in observed temperatures. The results quantify the amount of electricity used on diurnal time scales during a number of EHEs in a rapidly urbanising semi-arid metropolitan area (Phoenix, Arizona), indicating that cooling from AC contributes about 53\% of the overall daily electricity requirements during these periods. Electricity consumption peaked during late afternoon hours (roughly 3-6 p.m., locally), when the demand for AC approached two-thirds of the total hourly demand (Salamanca et al., 2013).

The multilayer building energy modelling (BEM) system, dynamically coupled to an atmospheric model, was designed to predict cooling/heating energy demand (i.e. the energy demand associated with ambient meteorological conditions) and has been applied at city scale for contemporary and future conditions associated with urban expansion (Salamanca et al., 2014, 2015). However, the BEM system alone is not able to predict the total energy demand because the human behaviour consumption element (i.e. the energy component that is not associated with the meteorology and therefore depends entirely on human behaviour) needs to be accounted for separately.

Salamanca et al. (2013) estimated the human behaviour consumption (i.e. base load), analysing citywide observed monthly mean electric loads for a specific year. For the Phoenix metropolitan area, minimum observed electric loads occurred 
during March and November, coinciding with moderate environmental weather conditions. These two months were considered the baseline months with negligible heating/cooling electric consumption. In this way and based on observed data, the diurnal cycle of the human behaviour consumption was computed, coupled with the meteorological component and used to calculate both electricity consumption and its contribution to the region's UHI (Salamanca et al., 2013, 2014, 2015).

With higher peak temperatures and longer hot periods anticipated in future summers, electrical demand by AC systems will have to be met by energy plants and the electric grid (Huang and Gurney, 2016). Reliable energy forecasting methods, such as the simulations described above, will be needed for resource planning of rapidly growing urban areas, particularly in the extreme conditions of semi-arid environments. Complicating such situations is the positive impact on air quality associated with the destabilisation of the planetary boundary layer (due to heat emission from AC units), which promotes night-time vertical mixing and underscores challenges of urban adaptation (Georgescu, 2015; Sharma et al., 2016). Therefore, compensating effects on thermal, air quality and other indicators underline the need for comprehensive markers that characterise the totality of urban-induced effects.

From an energy perspective, AC use is greatest during the same periods of extremely high temperatures that cause higher transmission losses and reduced thermal efficiencies at electric generation facilities. During a 2006 heatwave, electric power transformers failed in Missouri and New York, causing interruptions of the electric power supply. In addition, more than 2000 distribution line transformers in California failed during a July 2006 heatwave, causing loss of power to approximately 1.3 million customers. Research ascertaining the potential for individual and institutional adaptive strategies to lessen impacts due to extreme heat and, in particular, impacts on human health risk caused by blackouts is necessary to establish support tools aiding the development of novel protocols for heat risk emergency response monitoring and planning (Kuras et al., 2017). Thus, increased cooling demand may increase the occurrence of peak loads coinciding with periods when generation efficiencies are lowest. Furthermore, the effects of high temperatures may be exacerbated when wind speeds are low or night-time temperatures are high, preventing transmission lines from cooling. This is a particular concern because night-time temperatures have been increasing at a faster rate than daytime temperatures (e.g. Georgescu et al., 2013).

Comparison with observational data has demonstrated that the physics-based modelling system is an effective tool for assessing (indoor) urban cooling requirements, which involves evaluating electricity consumption for different urban growth patterns and under extreme summertime weather conditions. These studies will be crucial for the development of reliable projections on future cooling needs and environmental consequences of rapidly urbanising regions under various climate scenarios (Bartos and
Chester, 2015; Georgescu et al., 2012, 2014) that strategically incorporate adaptation and mitigation strategies alleviating energy demand (Georgescu et al., 2014; Salamanca et al., 2016).

\subsubsection{Example 2: Asian and subtropical cities}

These cities have shown how, when very low regional temperatures occur, temperatures can become even lower in urban areas as a result of air pollution or sand storms reducing solar radiation. The provision of heating that compensates for the cooling results in higher air pollution, subsequently exacerbating hazards associated with extreme low temperatures. The main hazards associated with pollutants in urban areas also arise from high concentrations of contaminants from industry, transport and agriculture, as well as particulates arising from natural sources (e.g. wind-blown sand or noxious gases from lakes) (Jacobson, 2012; Li et al. 2015, 2016a), and may cause serious health implications (Pope and Dockery, 2006).

As winds transport pollutants into an urban area, concentrations tend to increase in the downwind direction. At high temperatures during summer months, particularly in the tropics, climatic variations can induce low winds and high temperatures, which may be raised further by high emissions from static and moving sources, such as episodes in Athens in 1987 (Matzarakis and Mayer, 1991) and Moscow in 2010 (Shaposhnikov et al., 2014) and others in Beijing and Shanghai (Huang et al., 2010; Wang and Gong, 2010). Because road vehicles are the main source of polluting gases and particles in urban areas, and because journey distances (particularly for low-rise cities) increase as cities expand, emissions of air pollutants per unit area also increase in proportion to the diameter $L$. The transport of atmospheric boundary layer pollutants leads to the degradation of air quality downwind, over distances that, in some meteorological conditions, can extend hundreds of kilometres (Cheng and Chan, 2012).

As air pollutants are transported across the city, while some gases increase in concentration, others such as nitrogen oxides undergo chemical transformation and are reduced in the centre while increasing in the outer regions. Overall, the magnitude of the pollutant concentration increases with $L$. With anthropogenic climate change as an additional forcing agent, the sources of pollutant and heat increase in urban areas can be compounded by, for example, widespread use of AC in buildings and vehicles. Both hazards are worsened by lengthy periods of calm conditions, which are projected to occur with increased frequency under a future climate characterised by increased occurrence of synopticscale blocking (Cassou and Guilyardi, 2007; Li et al., 2012).

\subsubsection{Example 3: amplification of hazards in urban areas} Natural hazards arising outside urban areas are changed significantly within them. In some situations, different urban hazards act in combination. In the presence of high winds, including tropical cyclones (TCs) and tornadoes, although the resistance of buildings reduces the mean wind speeds over the urban areas compared with outside, locally, wind speeds can 
exceed rural wind speeds in gaps between buildings, and turbulent gusts are amplified (Britter and Hunt, 1979; Oke, 1987). In addition, because significant numbers of high-rise buildings are being built in often highly populous coastal cities that are subject to impacts from TCs, there is concern about the growing vulnerability of their inhabitants (McGranahan et al., 2007; Pielke, 2007). Although global climate change is increasing the average sea surface temperature and the average tropopause height, there is not yet any conclusive statistical evidence about the projected strength and frequency of TCs. However, there is evidence that the trajectories of those major TCs that reach land are changing and reaching latitudes lower than those they reached previously (e.g. in northern Malaysia). In general, the resistance to the airflow caused by the built environment tends to deflect onshore winds parallel to the coast while amplifying peak nearsurface winds (Chan and Chan, 2015; Hunt et al., 2004). As urban areas expand, this trend is likely to be amplified, which may also reduce the onshore movement of TCs. Coastal agricultural regions, either surrounding or within urban areas themselves, that rely on TC rainfall may be negatively affected if precipitation is reduced sufficiently, potentially resulting in increased irrigation demand to meet required yields.

Hydrological extremes in the form of drought and flood can be amplified in urban areas. The return period of intense precipitation over short periods $(100 \mathrm{~mm} / \mathrm{h})$ in Asia has decreased (e.g. from 37 to 18 years according to Hong Kong Observatory (2016); cf. Wong et al. (2011) and Lee et al. (2010)). The peak intensity of rainfall is likely to occur not only in geographical areas where the surface air flow converges, which can happen in mountains, but also within megacities, which affect regional climates (BensonLira et al., 2016; Chow et al., 2016; Holst et al., 2016; Georgescu et al., 2012; Shepherd et al., 2011; Smith et al., 2013). The prediction of rainfall and flooding in the low-lying and almost completely urbanised areas of the island of Singapore is improving as a result of detailed computational models and a dense network of real-time data (Chow et al., 2016; Pereira et al., 2014). Deeper convection caused by climate change effects on the troposphere makes such events more likely in future. Important impacts are also evident below the land surface-atmosphere interface. Decreased precipitation and increased evaporation associated with longer periods of droughts and high-temperature episodes are depleting underground reservoirs and natural aquifers. In India, reduced monsoon rains are lowering water levels in some lakes and rivers. Water shortages tend to be exacerbated both within and around expanding urban areas, particularly in Asia and Africa, where some city aquifers are now more than $30 \mathrm{~m}$ below ground level (Morris et al., 2003).

Flooding hazards in urban areas are partly caused by more rapid run-off from distant ice- and snow-covered mountains caused by global warming, or by agricultural practices such as reducing tree cover, which has been found to correlate with vulnerability against flooding (see the study by Pauleit et al. (2005) for a UK example). The results are seen in overflowing rivers and watercourses and in unconfined areas such as streets and fields. Many secondary effects occur in urban areas such as landslides, weaker foundations, collapsing structures (e.g. in Boulder, Colorado, USA, the floods of 2013 resulted in more than US\$1 billion in property damage) and loss of land into coastal seas, depending on local geography and infrastructure. In the Philippines, these secondary effects are found to influence the overall movement of floodwaters and the extent of danger to communities (DOST, 2012). The Tropical Cyclone Haiyan in 2013, upon reaching southern Philippines, caused unusually large damage to buildings and trees, in large part because over the shallow coastal waters, wind stress drove a large surge, lifting rocks from the seabed and transporting them several kilometres inland. Importantly, urban design strategies that include the incorporation of man-made rivers, reservoirs and planned flood areas have been shown to reduce local flooding hazards relative to surrounding areas, highlighting the importance of engineered infrastructure resilience as a potential adaptive mechanism.

Other hydrological hazards occur with wind- and earthquakeinduced surges and waves (or tsunamis) onto coasts (Fernando, 2008). Such hazards flood urban areas along coasts and along canals connected to the coasts (as occurred with Hurricane Ike; see the study by Kennedy et al. (2011)). Arctic coastal communities are now at risk from tsunamis generated by seismic activity that has until now been suppressed by sea ice. The examination of the tsunami waves of 2004, 2010 and 2011 in Asia and the Pacific has illustrated how such hazards are affected by similar physical and natural changes of climate (Klettner et al., 2012). As the tsunami in March 2011 reached the east coast of Japan, significant variability in the wave amplitude was observed and in the surge movement (backwards and forwards up the shore) before flooding of urban areas and the industrial plant at Fukushima.

\section{Discussion and conclusions}

This paper examines how extreme natural and artificial hazards in the atmosphere, hydrosphere and on land are becoming more severe and more frequent as global climate changes. The review emphasises the changing patterns and greater spatial variability of these hazards over different geographical and climatic regions. As a result, the observed trends and patterns of hazards are diverging from those of past decades and centuries. Existing models suggest that this divergence will grow in the future, with more intense, longer-duration and more frequent extreme events. The extent of the increase and variability in climate-induced hazards varies between regions and for each specific hazard (Table 1).

In growing megacities, these factors include their surface area extent, urban population and growth rate, urban design/ technology, socio-economic factors and overall societal behaviour.

In considering the major physical and natural causes of hazards, this paper also describes and analyses their societal effects, and future work will examine the impacts on policy development. The concept of societal effects extends beyond the useful, but essentially passive, concept of vulnerability. For example, 
Table 1. Relating environmental hazards to urbanisation and climate change factors

\begin{abstract}
Types of natural and artificial hazards arising from extreme environmental variations (positive or negative denoted by $+/-$ ) and/or increased persistence and/or increased frequency in
\end{abstract}

Urbanisation and vulnerability effects

Examples of significant hazards in large urban areas (a) Wind speed (+/-)

(b) Temperature $(+/-)$

(c) Natural and artificial pollutants/radiation in the atmosphere, land and water (+)

(d) Hydrological processes - for example, flooding, sea level rise/ drought (+/-)

(e) Primary and secondary geophysical hazards leading to environmental hazards - for example, earthquakes/tsunamis, volcanoes/landslides, floods/landslides, storm surges/floods, sand storms/air pollution (+)

(f) Biological/environmental - for example, disease, desertification (+)

Amplification or reduction of natural hazards (listed above); hazards associated with infrastructure and human activities in urban areas (dependent on size, location, design and economy of urban areas); complex hazards associated with natural and human influences on global, regional and urban environment - for example, higher/lower winds; higher temperatures, increased air pollution and increased/decreased water pollution; shortages/excesses of water

Coastal and/or riverine cities

New Orleans (a), Houston (a), New York (a, e, $f)$, Bangkok (d), Dhaka

$(a, d)$, Tokyo $(a, c, e)$, Hong Kong $(a, c, d)$, Jakarta $(c, e, f)$, Manila

$(a, c, d)$, Paris and London $(b, c, f)$

Inland cities

Phoenix $(b, c)$, Beijing $(b, c, f)$ Xian/other cities in central western China $(b, c, e), \operatorname{Moscow}(b, c, f)$, Athens $(b, c, f)$



Figure 3. System diagram for effects of hazards, impacts and policies associated with global climate change, growing urban areas and societal responses ( $T_{H}$, period of hazards; $T_{R}$, period of long-term impacts and recovery) 
communities have shown increasing capability to obtain and use information in advance of and during hazards (e.g. Hondula and Krishnamurthy, 2014) and are increasingly adept at moderating hazard impacts (e.g. reducing the magnitudes and social impacts of floods in urban areas; see Lagmay (2015)). The recovery of communities following hazards can reduce long-term impacts. Equally significant are the urban-biosphere interactions surrounding and within megacities, which have vast effects on health and the agriculture/forestry municipalities in Latin America and South-east Asia.

The diagram shown in Figure 3 illustrates how the 'dynamicalsystems' methodology (e.g. Wilson, 2000) facilitates a holistic overview (Smuts, 1926) and informs decisions about the empirical or scientifically based interactions, the various factors that influence or control some broadly connected collection of processes and organisations. Here, the authors are considering the links between global and regional climate changes and the processes and hazards that affect urban hazards, impacts and potential ameliorating policies (see Hunt (2009b) for complex relationships between these). The review presented here includes an appraisal of the impact on health, in particular the combination of temperature extremes and intense air pollution from traffic, heating and $\mathrm{AC}$ use and particulates entering cities from rural or upwind urban areas. The authors stress the value of comprehensive policy development accounting for place-based variability (Table 1) and therefore directly address compensating effects on thermal, air quality and other indicators that characterise the totality of urban-induced effects. Simultaneously, the authors acknowledge that wedge-type approaches (e.g. Pacala and Socolow, 2004) can provide insight into optimising the efficacy of urban policies, favouring some strategies over others.

The authors assert that involving different techniques for data analysis and system modelling is more appropriate for practical decision making than the purely reductionist approach that builds up semi-empirical models and connects them to basic data of all the various factors (e.g. Hunt et al., 2012). The utility of such methods should ensure increasingly pragmatic approaches to planning the form(s), size(s) and overall future growth of built environments, as well as the development of appropriate policies for green infrastructure and societal behaviour that will lower energy use. To achieve success, however, will require action that is in concert with societally informed decision makers, grounded on sound scientific achievements. Collectively, these actions will determine the future environment of megacities.

\section{Acknowledgements}

This research was supported at Arizona State University by the National Science Foundation grants Sustainable Research Network CBET-1444758, SES-1520803, DMS-1419593 and US Department of Agriculture National Institute of Food and Agriculture grant 2015-67003-23508. The authors are grateful to Professor Yuguo Li and colleagues at the Hong Kong University for funding Professor Julian Hunt as a visiting professor. Professor Julian Hunt and
Dr Yasemin D. Aktas were supported by the Malaysian Commonwealth Studies Centre at University of Cambridge and the project 'Future Cities: Science to Action for Building Resilience of Urban Communities to Climate Induced Physical Hazards' funded by the British Council-Newton Ungku Omar Fund.

\section{REFERENCES}

Aguilar AG (2008) Peri-urbanization, illegal settlements and environmental impact in Mexico City. Cities 25(3): 133-145, http://dx. doi.org/10.1016/j.cities.2008.02.003.

Akimoto H (2003) Global air quality and pollution. Science 302(5651): 1716-1719, http://dx.doi.org/10.1126/science.1092666.

Andrew JT (2009) Adapt, flee, or perish: responses to climate change for California's water sector. Proceedings of the Ice, Snow and Water Workshop, San Diego, CA, USA.

Bartos MD and Chester MV (2015) Impacts of climate change on electric power supply in the Western United States. Nature Climate Change 5(8): 748-752, http://dx.doi.org/10.1038/nclimate2648.

Batty M (2008) The size, scale, and shape of cities. Science 319(5864): 769-771, http://dx.doi.org/10.1126/science.1151419.

Benson-Lira V, Georgescu M, Kaplan S and Vivoni ER (2016) Loss of a lake system in a megacity: the impact of urban expansion on seasonal meteorology in Mexico City. Journal of Geophysical Research: Atmospheres 121(7): 3079-3099, http://dx.doi.org/10.1002/ 2015JD024102.

Bohnenstengel SI, Evans S, Clark PA and Belcher SE (2011) Simulations of the London urban heat island. Quarterly Journal of the Royal Meteorological Society 137(659): 1625-1640, http://dx.doi.org/10. 1002/qj.855.

Britter RE and Hunt JC (1979) Velocity measurements and order of magnitude estimates of the flow between two buildings in a simulated atmospheric boundary layer. Journal of Wind Engineering and Industrial Aerodynamics 4(2): 165-182, http://dx.doi.org/10.1016/ 0304-3908(79)90044-4.

Broecker W (2010) The Great Ocean Conveyor, Discovering the Trigger for Abrupt Climate Change. Princeton University Press, Princeton, NJ, USA.

Carrington D (2016) Electric cars 'will be cheaper than conventional vehicles by 2022'. The Guardian, 25 February. See http://www. theguardian.com/environment/2016/feb/25/electric-cars-will-becheaper-than-conventional-vehicles-by-2022 (accessed 01/03/2016).

Cassou C and Guilyardi É (2007) Modes de variabilité et changement climatique. La Météorologie 59: 22-30, http://dx.doi.org/10.4267/ 2042/14844 (in French).

Chan KT and Chan JC (2015) Impacts of vortex intensity and outer winds on tropical cyclone size. Quarterly Journal of the Royal Meteorological Society 141(687): 525-537, http://dx.doi.org/10.1002/ qj. 2374.

Chan CK and Yao X (2008) Air pollution in mega cities in China. Atmospheric Environment 42(1): 1-42, http://dx.doi.org/10.1016/j. atmosenv.2007.09.003.

Cheng CK and Chan JC (2012) Impacts of land use changes and synoptic forcing on the seasonal climate over the Pearl River Delta of China. Atmospheric Environment 60: 25-36, http://dx.doi.org/10.1016/j. atmosenv.2012.06.019.

Cheung HN, Zhou W, Mok YH and Wu MC (2012) Relationship between Ural-Siberian blocking and the East Asian winter monsoon in relation to the Arctic Oscillation and the El Niño-Southern Oscillation. Journal of Climate 25(12): 4242-4257, http://dx.doi.org/10.1175/ JCLI-D-11-00225.1.

Chow WT, Cheong BD and Ho BH (2016) A multimethod approach towards assessing urban flood patterns and its associated vulnerabilities in Singapore. Advances in Meteorology 2016: 7159132, http://dx.doi.org/10.1155/2016/7159132. 
Connors JP, Galletti CS and Chow WT (2013) Landscape configuration and urban heat island effects: assessing the relationship between landscape characteristics and land surface temperature in Phoenix, Arizona. Landscape Ecology 28(2): 271-283, http://dx.doi.org/10.1007/s10980012-9833-1.

Declet-Barreto J, Brazel AJ, Martin CA, Chow WT and Harlan SL (2013) Creating the park cool island in an inner-city neighborhood: heat mitigation strategy for Phoenix, AZ. Urban Ecosystems 16(3): 617-635, http://dx.doi.org/10.1007/s11252-012-0278-8.

DOST (Department of Science and Technology) (2012) DOST-Project NOAH. DOST, Taguig, Philippines. See http://noah.dost.gov.ph/ (accessed 04/01/2016).

Eakin H, Bojórquez-Tapia LA, Janssen MA et al. (2017) Opinion: urban resilience efforts must consider social and political forces. Proceedings of the National Academy of Sciences of the United States of America 114(2): 186-189, http://dx.doi.org/10.1073/pnas.1620081114.

Ehrenfeld JG (2000) Evaluating wetlands within an urban context. Ecological Engineering 15(1): 253-265, http://dx.doi.org/10.1023/ A: 1009543920370 .

Elsner JB, Elsner SC and Jagger TH (2015) The increasing efficiency of tornado days in the United States. Climate Dynamics 45(3-4): 651-659, http://dx.doi.org/10.1007/s00382-014-2277-3.

Fernando HJ (2008) Polimetrics: the quantitative study of urban systems (and its applications to atmospheric and hydro environments). Environmental Fluid Mechanics 8(5): 397-409, http://dx.doi.org/10. 1007/s10652-008-9116-1.

Georgescu M (2015) Challenges associated with adaptation to future urban expansion. Journal of Climate 28(7): 2544-2563, http://dx.doi. org/10.1175/JCLI-D-14-00290.1.

Georgescu M, Miguez-Macho G, Steyaert LT and Weaver CP (2009) Climatic effects of 30 years of landscape change over the Greater Phoenix, Arizona, region: 2: dynamical and thermodynamical response. Journal of Geophysical Research 114(D5): D05111, http:// dx.doi.org/10.1029/2008JD010762.

Georgescu M, Mahalov A and Moustaoui M (2012) Seasonal hydroclimatic impacts of Sun Corridor expansion. Environmental Research Letters 7(3), http://dx.doi.org/10.1088/1748-9326/7/3/ 034026.

Georgescu M, Moustaoui M, Mahalov A and Dudhia J (2013) Summertime climate impacts of projected megapolitan expansion in Arizona. Nature Climate Change 3(1): 37-41, http://dx.doi.org/10.1038/ nclimate1656.

Georgescu M, Morefield PE, Bierwagen BG and Weaver CP (2014) Urban adaptation can roll back warming of emerging megapolitan regions. Proceedings of the National Academy of Sciences of the United States of America 111(8): 2909-2914, http://dx.doi.org/10.1073/pnas. 1322280111.

Georgescu M, Chow WT, Wang ZH et al. (2015) Prioritizing urban sustainability solutions: coordinated approaches must incorporate scale-dependent built environment induced effects. Environmental Research Letters 10(6): 061001, http://dx.doi.org/10.1088/1748-9326/ $10 / 6 / 061001$.

Grimm NB, Faeth SH, Golubiewski NE et al. (2008) Global change and the ecology of cities. Science 319(5864): 756-760, http://dx.doi.org/10. 1126/science.1150195.

Guo L, Wang K and Bluestein HB (2016) Variability of tornado occurrence over the continental United States since 1950. Journal of Geophysical Research: Atmospheres 121(12): 6943-6953, http://dx.doi.org/10. 1002/2015JD024465.

Hajat S, Kovats RS and Lachowycz K (2007) Heat-related and cold-related deaths in England and Wales: who is at risk? Occupational and Environmental Medicine 64(2): 93-100, http://dx.doi.org/10.1136/oem. 2006.029017.

Hajat S, Vardoulakis S, Heaviside C and Eggen B (2014) Climate change effects on human health: projections of temperature-related mortality for the UK during the 2020s, 2050s and 2080s. Journal of Epidemiology and Community Health 68(7): 641-648, http://dx.doi. org/10.1136/jech-2013-202449.

Heim JJ (2015) An overview of weather and climate extremes - products and trends. Weather and Climate Extremes 10(B): 1-9, http://dx.doi. org/10.1016/j.wace.2015.11.001.

Holst CC, Tam CY and Chan JCL (2016) Sensitivity of urban rainfall to anthropogenic heat flux: a numerical experiment. Geophysical Research Letters 43(5): 2240-2248, http://dx.doi.org/10.1002/ 2015 GL067628.

Hondula DM and Krishnamurthy R (2014) Emergency management in the era of social media. Public Administration Review 74(2): 274-277, http://dx.doi.org/10.1111/puar.12184.

Hondula DM, Vanos JK and Gosling SN (2014) The SSC: a decade of climate-health research and future directions. International Journal of Biometeorology 58(2): 109-120, http://dx.doi.org/10.1007/s00484012-0619-6.

Hong Kong Observatory (2016) Observed Climate Change in Hong KongExtreme Weather Events. Hong Kong Observatory, Tsim Sha Tsui, Hong Kong. See http://www.hko.gov.hk/prtver/html/docs/climate change/ obs_hk_extreme_weather_e.shtml (accessed 02/01/2016).

Hoshiko S, English P, Smith D and Trent R (2010) A simple method for estimating excess mortality due to heat waves, as applied to the 2006 California heat wave. International Journal of Public Health 55(2): 133-137, http://dx.doi.org/10.1007/s00038-009-0060-8.

Houghton RA (2015) Land-Use Change and Tropical Forests, 5th edn. Cambridge University Press, Cambridge, UK.

Hov Ø, Cubasch U, Fischer E et al. (2013) Extreme Weather Events in Europe: Preparing for Climate Change Adaptation. Norwegian Meteorological Institute, Oslo, Norway; European Academies Science Advisory Council, Halle, Germany.

Huang J and Gurney KR (2016) Impact of climate change on US building energy demand: sensitivity to spatiotemporal scales, balance point temperature, and population distribution. Climatic Change 137(1): 171-185, http://dx.doi.org/10.1007/s10584-016-1681-6.

Huang W, Kan H and Kovats S (2010) The impact of the 2003 heat wave on mortality in Shanghai, China. Science of the Total Environment 408(11): 2418-2420, http://dx.doi.org/10.1016/j.scitotenv.2010.02.009.

Hunt JC (2005) London's Environment: Prospects for a Sustainable World City. Imperial College Press, London, UK.

Hunt JC (2009a) Integrated policies for environmental resilience and sustainability. Proceedings of Institution of Civil Engineers Engineering Sustainability 162(3): 155-167, http://dx.doi.org/10.1680/ ensu.2009.162.3.155.

Hunt JC (2009b) Implications of climate change for expanding cities world-wide. Proceedings of the 9th AMS Presidential Forum: Urban Weather and Climate - Now and the Future, Phoenix, AZ, USA.

Hunt J (2013) Research in environmental fluid dynamics and its policy implication. In Handbook of Environmental Fluid Dynamics (Fernando HJS (ed.)). CRC Press, Boca Raton, FL, USA, vol. 1, pp. $19-35$

Hunt JC and Hangan H (2013) New Storm Patterns Require New Wind Engineering. Thomson Reuters Foundation, London, UK. See http:// www.trust.org/item/20131029170556-lg0ta/ (accessed 21/11/2015).

Hunt JC and Li Y (2014) Will Climate Change Drive a Revolution in Building Design? Thomson Reuters Foundation. London, UK. See http://www.trust. org/item/20140828085050-aq0j4/ (accessed 06/02/2017).

Hunt JC, Mitchell JF and Tett SF (1996) Mathematical and physical basis of general circulation models of climate. Zeitschrift für Angewandte Mathematik und Mechanik 76(S4): 501-508.

Hunt JC, Orr A, Rottman JW and Capon R (2004) Coriolis effects in mesoscale flows with sharp changes in surface conditions. Quarterly Journal of the Royal Meteorological Society 130(603): 2703-2731, http://dx.doi.org/10.1256/qj.04.14. 
Hunt JC, Kopec G and Aplin K (2010) Tsunamis and geophysical warnings. Astronomy \& Geophysics 51(5): 5.37-5.38, https://doi.org/ 10.1111/j.1468-4004.2010.51537.x.

Hunt JC, Timoshkina YV, Bohnenstengel SI and Belcher S (2011) Implications of climate change for expanding cities worldwide. Proceedings of the Institution of Civil Engineers - Urban Design and Planning 166(4): 241-254, http://dx.doi.org/10.1680/udap.10. 00062.

Hunt JC, Timoshkina Y, Baudain PJ and Bishop SR (2012) System dynamics applied to operations and policy decisions. European Review 20(3): 324-342, http://dx.doi.org/10.1017/S1062798711000585.

Hunt JC, Chan JC and Wu J (2016) Asian urban environment and climate change. Current Science 110(8): 1398-1400.

Huynen MM, Martens P, Schram D, Weijenberg MP and Kunst AE (2001) The impact of heat waves and cold spells on mortality rates in the Dutch population. Environmental Health Perspectives 109(5): 463-470, http://dx.doi.org/10.2307/3454704.

IPCC (Intergovernmental Panel on Climate Change) (2012) Managing the Risks of Extreme Events and Disasters to Advance Climate Change Adaptation: a Special Report of Working Groups I and II of the Intergovernmental Panel on Climate Change. Cambridge University Press, Cambridge, UK.

IPCC (2014) Summary for policymakers. In Climate Change 2014. Mitigation of Climate Change - Contribution of Working Group III to the Fifth Assessment Report of the Intergovernmental Panel on Climate Change (Edenhofer O, Pichs-Madruga R, Sokona Y et al. (eds)). Cambridge University Press, Cambridge, UK, pp. 1-32.

Jacobson MZ (2012) Air Pollution and Global Warming, 2nd edn. Cambridge University Press, New York, NY, USA.

Kammen DM and Sunter DA (2016) City-integrated renewable energy for urban sustainability. Science 352(6288): 922-928, http://dx.doi.org/10. 1126/science.aad9302.

Kennedy AB, Gravois U, Zachry BC et al. (2011) Origin of the Hurricane Ike forerunner surge. Geophysical Research Letters 38(8): 1-5, http:// dx.doi.org/10.1029/2011GL047090.

Klettner CA, Balasubramanian S, Hunt JC et al. (2012) Draw-down and run-up of tsunami waves on sloping beaches. Proceedings of the Institution of Civil Engineers - Engineering and Computational Mechanics 165(2): 119-129, http://dx.doi.org/10.1680/eacm.10.00044.

Kuras ER, Bernhard MC, Calkins MM et al. (2017) Opportunities and challenges for personal heat exposure research. Environmental Health Perspectives (in press).

Lagmay A (2015) NOAH - linking science and communities. Proceedings of the 5th ANCST Workshop on Climate Change ad Disaster Resilience - Post Sendai 2015, Manila, Philippines.

Lawson N (2008) An Appeal to Reason: a Cool Look at Global Warming. Duckworth Overlook, London, UK.

Lee SY, Dunn RJ, Young RA et al. (2006) Impact of urbanization on coastal wetland structure and function. Austral Ecology 31(2): 149-163, http://dx.doi.org/10.1111/j.1442-9993.2006.01581.x.

Lee BY, Mok HY and Lee TC (2010) The Latest on Climate Change in Hong Kong and Its Implications for the Engineering Sector. Hong Kong Observatory, Tsim Sha Tsui, Hong Kong.

Lenton TM, Held H, Kriegler E et al. (2008) Tipping elements in the Earth's climate system. Proceedings of the National Academy of Sciences of the United States of America 105(6): 1786-1793, http://dx. doi.org/10.1073/pnas.0705414105.

Lentz DL, Dunning NP, Scarborough VL et al. (2014) Forests, fields, and the edge of sustainability at the ancient Maya city of Tikal. Proceedings of the National Academy of Sciences of the United States of America 111(52): 18513-18518, http://dx.doi.org/10.1073/pnas. 1408631111.

Li XX and Norford LK (2016) Evaluation of cool roof and vegetations in mitigating urban heat island in a tropical city, Singapore. Urban Climate 16: 59-74, http://dx.doi.org/10.1016/j.uclim.2015.12.002.
Li W, Li L, Ting M and Liu Y (2012) Intensification of Northern Hemisphere subtropical highs in a warming climate. Nature Geoscience 5(11): 830-834, http://dx.doi.org/10.1038/ngeo1590.

Li D, Bou-Zeid E, Baeck ML, Jessup S and Smith JA (2013a) Modeling land surface processes and heavy rainfall in urban environments: sensitivity to urban surface representations. Journal of Hydrometeorology 14(4): 1098-1118, http://dx.doi.org/10.1175/JHM-D-12-0154.1.

Li XX, Koh TY, Entekhabi D et al. (2013b) A multi-resolution ensemble study of a tropical urban environment and its interactions with the background regional atmosphere. Journal of Geophysical Research: Atmospheres 118(17): 9804-9818, http://dx.doi.org/10.1002/jgrd. 50795.

Li J, Georgescu M, Hyde P, Mahalov A and Moustaoui M (2015) Regionalscale transport of air pollutants: impacts of Southern California emissions on Phoenix ground-level ozone concentrations. Atmospheric Chemistry and Physics 15(16): 9345-9360, http://dx.doi.org/10.5194/ acp-15-9345-2015.

Li J, Mahalov A and Hyde P (2016a) Impacts of agricultural irrigation on ozone concentrations in the central valley of California and in the contiguous United States based on WRF-Chem simulations. Agricultural and Forest Meteorology 221: 34-49, http://dx.doi.org/10. 1016/j.agrformet.2016.02.004.

Li D, Malyshev S and Shevliakova E (2016b) Exploring historical and future urban climate in the Earth System Modeling Framework: 1. Model development and evaluation. Journal of Advances in Modeling Earth Systems 8(2): 917-935, http://dx.doi.org/10.1002/ 2015MS000578.

Li D, Malyshev S and Shevliakova E (2016c) Exploring historical and future urban climate in the Earth System Modeling Framework: 2. Impact of urban land use over the Continental United States. Journal of Advances in Modeling Earth Systems 8(2): 936-953, http://dx.doi. org/10.1002/2015MS000579.

Lin J, Pan D, Davis SJ et al. (2014) China's international trade and air pollution in the United States. Proceedings of the National Academy of Sciences of the United States of America 111(5): 1736-1741, http://dx. doi.org/10.1073/pnas.1312860111.

Madlener R and Sunak Y (2011) Impacts of urbanization on urban structures and energy demand: what can we learn for urban energy planning and urbanization management? Sustainable Cities and Society 1(1): 45-53, http://dx.doi.org/10.1016/j.scs.2010.08.006.

Maggiotto G, Buccolieri R, Santo MA, Leo LS and di Sabatino S (2014) Validation of temperature-perturbation and CFD-based modelling for the prediction of the thermal urban environment: the Lecce (IT) case study. Environmental Modelling \& Software 60: 69-83, http://dx.doi. org/10.1016/j.envsoft.2014.06.001.

Matthews T, Mullan D, Wilby RL, Broderick C and Murphy C (2016) Past and future climate change in the context of memorable seasonal extremes. Climate Risk Management 11: 37-52, http://dx.doi.org/10. 1016/j.crm.2016.01.004.

Matzarakis A and Mayer H (1991) The extreme heat wave in Athens from the point of view of human biometeorology. Atmospheric Environment: Part B: Urban Atmosphere 25(2): 203-211.

McGranahan G, Balk D and Anderson B (2007) The rising tide: assessing the risks of climate change and human settlements in low elevation coastal zones. Environment and Urbanization 19(1): 17-37, http://dx. doi.org/10.1177/0956247807076960.

Middel A, Chhetri N and Quay R (2015) Urban forestry and cool roofs: assessment of heat mitigation strategies in Phoenix residential neighborhoods. Urban Forestry \& Urban Greening 14(1): 178-186, http://dx.doi.org/10.1016/j.ufug.2014.09.010.

Morris BL, Lawrence ARL, Chilton PJC et al. (2003) Groundwater and Its Susceptibility to Degradation: a Global Assessment of the Problem and Options for Management. UN Environment Programme, Nairobi, Kenya, Early Warning and Assessment Report Series, RS. 03-3. See http://nora. nerc.ac.uk/19395/1/Groundwater_INC_cover.pdf (accessed 09/08/2016). 
Notz D (2009) The future of ice sheets and sea ice: between reversible retreat and unstoppable loss. Proceedings of the National Academy of Sciences of the United States of America 106(49): 20590-20595, http://dx.doi.org/10.1073/pnas.0902356106.

Oke TR (1987) Boundary Layer Climates. Methuen, London, UK

O'Neill MS and Ebi KL (2009) Temperature extremes and health: impacts of climate variability and change in the United States. Journal of Occupational and Environmental Medicine 51(1): 13-25, http://dx.doi. org/10.1097/JOM.0b013e318173e122.

Pacala S and Socolow R (2004) Stabilization wedges: solving the climate problem for the next 50 years with current technologies. Science 305(5686): 968-972, http://dx.doi.org/10.1126/science.1100103.

Pauleit S, Ennos R and Golding Y (2005) Modeling the environmental impacts of urban land use and land cover change - a study in Merseyside, UK. Landscape and Urban Planning 71(2-4): 295-310, http://dx.doi.org/10.1016/j.landurbplan.2004.03.009.

Pereira JJ, Hunt JCR and Chan JCL (2014) Science and technology for disaster prevention and climate resilience in Asia. ASM Science Journal 8(1): 1-10

Pelly JL and Hoskins BJ (2003) A new perspective on blocking. Journal of the Atmospheric Sciences 60(5): 743-755, http://dx.doi.org/10.1175/ 1520-0469(2003)060<0743:ANPOB $>2.0 . \mathrm{CO} ; 2$.

Pielke RA Jr (2007) Future economic damage from tropical cyclones: sensitivities to societal and climate changes. Philosophical Transactions of the Royal Society A 365(1860): 2717-2729, http://dx. doi.org/10.1098/rsta.2007.2086.

Pope CA and Dockery DW (2006) Health effects of fine particulate air pollution: lines that connect. Journal of the Air \& Waste Management Association 56(6): 709-742, http://dx.doi.org/10.1080/10473289.2006 10464485.

Rupp RF, Vásquez NG and Lamberts R (2015) A review of human thermal comfort in the built environment. Energy and Buildings 105: 178-205, http://dx.doi.org/10.1016/j.enbuild.2015.07.047.

Sailor DJ (2011) A review of methods for estimating anthropogenic heat and moisture emissions in the urban environment. International Journal of Climatology 31(2): 189-199, http://dx.doi.org/10.1002/joc.2106.

Sailor DJ (2014) Risks of summertime extreme thermal conditions in buildings as a result of climate change and exacerbation of urban heat islands. Building and Environment 78: 81-88, http://dx.doi.org/10. 1016/j.buildenv.2014.04.012.

Salamanca F, Georgescu M, Mahalov A et al. (2013) Assessing summertime urban air conditioning consumption in a semiarid environment. Environmental Research Letters 8(3): 034022, http://dx. doi.org/10.1088/1748-9326/8/3/034022.

Salamanca F, Georgescu M, Mahalov A, Moustaoui M and Wang M (2014) Anthropogenic heating of the urban environment due to air conditioning. Journal of Geophysical Research: Atmospheres, American Geophysical Union 119(10): 5949-5965, http://dx.doi.org/ 10.1002/2013JD021225.

Salamanca F, Georgescu M, Mahalov A and Moustaoui M (2015) Summertime response of temperature and cooling energy demand to urban expansion in a semiarid environment. Journal of Applied Meteorology and Climatology 54(8): 1756-1772, http://dx.doi.org/10. 1175/JAMC-D-14-0313.1.

Salamanca F, Georgescu M, Mahalov A, Moustaoui M and Martilli A (2016) Citywide impacts of cool roof and rooftop solar photovoltaic deployment on near-surface air temperature and cooling energy demand. Boundary-Layer Meteorology 161(1): 203-221, http://dx.doi. org/10.1007/s10546-016-0160-y.

Salvati L, Munafo M, Morelli VG and Sabbi A (2012) Low-density settlements and land use changes in a Mediterranean urban region. Landscape and Urban Planning 105(1-2): 43-52, http://dx.doi.org/10. 1016/j.landurbplan.2011.11.020.

Satterthwaite D (2008) Cities' contribution to global warming: notes on the allocation of greenhouse gas emissions. Environment and
Urbanization 20(2): 539-549, http://dx.doi.org/10.1177/ 0956247808096127.

Schneider A, Friedl MA and Potere D (2010) Mapping global urban areas using MODIS 500-m data: new methods and datasets based on 'urban ecoregions'. Remote Sensing of Environment 114(8): 1733-1746, http://dx.doi.org/10.1016/j.rse.2010.03.003.

Schellnhuber HJ, Crutzen PJ, Clark WC, Claussen M and Held H (2004) Earth System Analysis for Sustainability. MIT Press, Cambridge, MA, USA.

Shaffer SR, Moustaoui M, Mahalov A and Ruddell BL (2016) A method of aggregating heterogeneous subgrid land cover input data for multi-scale urban parameterization. Journal of Applied Meteorology and Climatology 55(9): 1889-1905, http://dx.doi.org/10.1175/JAMC-D-16-0027.1.

Shao M, Tang X, Zhang Y and Li W (2006) City clusters in China: air and surface water pollution. Frontiers in Ecology and the Environment 4(7): 353-361, http://dx.doi.org/10.1890/1540-9295(2006)004[0353: CCICAA]2.0.CO;2.

Shaposhnikov D, Revich B, Bellander T et al. (2014) Mortality related to air pollution with the Moscow heat wave and wildfire of 2010. Epidemiology 25(3): 359-364, http://dx.doi.org/10.1097/EDE. 0000000000000090

Sharma A, Conry P, Fernando HJS et al. (2016) Green and cool roofs to mitigate urban heat island effects in the Chicago metropolitan area: evaluation with a regional climate model. Environmental Research Letters 11(6): 064004, http://dx.doi.org/10.1088/1748-9326/11/6/064004.

Shepherd M, Mote T, Dowd J et al. (2011) An overview of synoptic and mesoscale factors contributing to the disastrous Atlanta flood of 2009 Bulletin of the American Meteorological Society 92(7): 861-870, http://dx.doi.org/10.1175/2010BAMS3003.1.

Smith BK, Smith JA, Baeck ML, Villarini G and Wright DB (2013) Spectrum of storm event hydrologic response in urban watersheds. Water Resources Research 49(5): 2649-2663, http://dx.doi.org/10. 1002/wrcr.20223.

Smuts JC (1926) Holism and Evolution. Macmillan, London, UK.

Solomon S, Plattner GK, Knutti R and Friedlingstein P (2009) Irreversible climate change due to carbon dioxide emissions. Proceedings of the National Academy of Sciences of the United States of America 106(6): 1704-1709, http://dx.doi.org/10.1073/pnas.0812721106.

Stern N (2006) The Economics of Climate Change: the Stern Review. Her Majesty's Treasury, London, UK.

Swart NC, Fyfe JC, Hawkins E, Kay JE and Jahn A (2015) Influence of internal variability on Arctic sea-ice trends. Nature Climate Change 5: 86-89, http://dx.doi.org/10.1038/nclimate2483.

Taleghani M, Tenpierik M, Kurvers S and van den Dobbelsteen A (2013) A review into thermal comfort in buildings. Renewable and Sustainable Energy Reviews 26: 201-215, http://dx.doi.org/10.1016/j. rser.2013.05.050.

Tan Z, Lau KKL and Ng E (2016) Urban tree design approaches for mitigating daytime urban heat island effects in a high-density urban environment. Energy and Buildings 114: 265-274, http://dx.doi.org/10. 1016/j.enbuild.2015.06.031.

ten Hoeve JE, Jacobson MZ and Remer LA (2012) Comparing results from a physical model with satellite and in situ observations to determine whether biomass burning aerosols over the Amazon brighten or burn off clouds. Journal of Geophysical Research 117(D8): 1-19, http://dx. doi.org/10.1029/2011JD016856.

Tietsche S, Notz D, Jungclaus JH and Marotzke J (2011) Recovery mechanisms of Arctic summer sea ice. Geophysical Research Letters 38(2): 1-4, http://dx.doi.org/10.1029/2010GL045698.

Tollefson J (2016) Global warming hiatus debate flares-up again. Nature, http://dx.doi.org/10.1038/nature.2016.19414.

UN (United Nations) (1996) Report of the United Nations Conference on Human Settlements (Habitat II). UN, New York, NY, USA. See https://www.un.org/ruleoflaw/wp-content/uploads/2015/10/istanbuldeclaration.pdf (accessed 11/12/2015). 
UN (2007) City Planning Will Determine Pace of Global Warming, UNHABITAT Chief Tells Second Committee as She Links Urban Poverty with Climate Change. UN, New York, NY, USA. See http://www.un. org/press/en/2007/gaef3190.doc.htm (accessed 08/12/2015).

UN (2014) World Urbanizations Prospects: the 2014 Revision, Highlights. UN, New York, NY, USA, ST/ESA/SER.A/352. See https://esa.un.org/ unpd/wup/Publications/Files/WUP2014-Highlights.pdf (accessed 08/ 08/2016).

US Department of Energy (2013) Sector Vulnerabilities to Climate Change and Extreme Weather. US Department of Energy, Washington, DC, USA. See https://energy.gov/sites/prod/files/2013/07/f2/20130710Energy-Sector-Vulnerabilities-Report.pdf (accessed 13/12/2015).

Wang XQ and Gong YB (2010) The impact of urban dry island on the summer heat wave and sultry weather in Beijing City. Chinese Science Bulletin 55(16): 1657-1661, http://dx.doi.org/10.1007/s11434-010$3088-5$.

Wilson AG (2000) Complex Spatial Systems: the Modelling Foundations of Urban and Regional Analysis. Pearson Education, London, UK.

WMO (World Meteorological Organization) (2013) The Global Climate 2001-2010: a Decade of Climate Extremes Summary Report. WMO, Geneva, Switzerland.

Wong MC, Mok HY and Lee TC (2011) Observed changes in extreme weather indices in Hong Kong. International Journal of Climatology 31(15): 2300-2311, http://dx.doi.org/10.1002/joc.2238.
World Bank (2017) http://data.worldbank.org/indicator/SP.URB.TOTL.IN. ZS (accessed 06/02/2017).

Yang Z, Dominguez F, Gupta H, Zeng X and Norman L (2016a) Urban effects on regional climate: a case study in the Phoenix and Tucson 'sun corridor'. Earth Interactions 20(20): 1-25, http://dx.doi.org/10. 1175/EI-D-15-0027.1.

Yang X, Li Y, Luo Z and Chan PW (2016b) The urban cool island phenomenon in a high-rise high-density city and its mechanisms. International Journal of Climatology 37(2): 890-904, http://dx.doi. org/10.1002/joc. 4747 .

Yang J, Wang ZH, Georgescu M, Chen F and Tewari M (2016c) Assessing the impact of enhanced hydrological processes on urban hydrometeorology with application to two cities in contrasting climates. Journal of Hydrometeorology 17(4): 1031-1047, http://dx. doi.org/10.1175/JHM-D-15-0112.1.

Zhang DL, Shou YX, Dickerson RR and Chen F (2011) Impact of upstream urbanization on the urban heat island effects along the Washington-Baltimore corridor. Journal of Applied Meteorology and Climatology 50(10): 2012-2029, http://dx.doi.org/10.1175/JAMC-D$10-05008.1$.

Zhou W, Huang G and Cadenasso ML (2011) Does spatial configuration matter? Understanding the effects of land cover pattern on land surface temperature in urban landscapes. Landscape and Urban Planning 102(1): 54-63, http://dx.doi.org/10.1016/j.landurbplan.2011.03.009.

\section{How can you contribute?}

To discuss this paper, please email up to 500 words to the editor at journals@ice.org.uk. Your contribution will be forwarded to the author(s) for a reply and, if considered appropriate by the editorial board, it will be published as discussion in a future issue of the journal.

Proceedings journals rely entirely on contributions from the civil engineering profession (and allied disciplines).

Information about how to email your paper online is available at www.icevirtuallibrary.com/page/authors, where you will also find detailed author guidelines. 